\title{
Causes Of Youth Restiveness In Niger Delta Region Of Nigeria: Implication Of Violent Youth Behavior For National Unity And Sustainability
}

\author{
Ogbadu Ruth Alewo, Ausa Benedict Usman, and Atadoga Margaret Ayanigo
}

\begin{abstract}
This paper investigated the characteristics of the Niger Delta Youths Restiveness and concludes that it is tantamount to national disintegration, rather than national sustainability. The growing and widespread youth restiveness and their involvement in violent crimes in recent times have become a matter of great concern for those genuinely interested in the unity and sustainability of his country. This is more so that the youths represent the collective aspirations of this country for a better tomorrow. Therefore, their involvement in all forms of violence and crime pose a great threat to the survival of the country. This paper closely looked at the causes, forms and Implication of Violent Youth Behavior for National Unity and Sustainability. The paper also recommends that the educational system be reviewed to lay more emphasis on the acquisition of manipulative skills for gainful self-employment as well as the creation of more employment opportunities for the youths.
\end{abstract}

Index Terms - Causes; National Unity; Niger Delta Region; Nigeria; Implication; Youth Restiveness; Sustainability; Violent; Youth Behavior.

\section{INTRODUCTION}

Toward the last quarter of the $20^{\text {th }}$ century and the beginning of the 21th century, the business of governance the world over had changed phase because of people's yearning for dignity and rights of man, which are enshrined in freedom, liberty and equality. The business of government centered around various forms of government such as monarchy, aristocracy, fascism, democracy, etc. All these forms of government are to pave way for human dignity and independence.

Owing to this statement, The National Policy on Education (FRN, 1998) posit that the overall philosophy of Nigeria is to "live in unity and harmony as one indivisible, indissoluble, democratic and sovereign nation founded on the principles of freedom, equality and justice, promote inter-African Solidarity and world peace through understanding", to achieve these objectives, the national goals which derive from this philosophy are:

a. The inculcation of national consciousness and national unity.

b. The inculcation of the right type of values and attitudes for the survival individual and the Nigerian society. c. The training of the mind in the understanding of the world around, and

d. The acquisition of appropriate skills and development of mental, physical and social abilities and competencies for the individual to live and contribute to the development of the society.

No doubt these goals appear novel and lofty and if implemented, will bring about the much needed positive changes we are all desirous of witnessing.

However, the current trends of youth restiveness and violence who are the future leader of this country do not call for cheer. On daily basis, the print and electronic media are replete with reports of one kind of youth violence or the other. These range from their involvement in armed robbery, cult activities on campus, political thuggery to our sit-tight politicians, members of ethnic militias such as OPC, Bakassi Boys, Area Boys, Egbesu, Niger Delta Youths, Almajirais, Ijaw youth, to mention but few. This is a disturbing trend and posse's great danger to national unity and development and to say the least, our nascent democracy (Madas 2007).

The do or die affair for resource control concerns the youth not because they constitute the majority in the population $(80 \%)$ but also that they are the most militant and violate groups that perpetuate the destruction of lives and property. They are also causing havoc to bring to attention the plight of the Niger Delta people; in their desire to control the mineral resources obtained in their area; inspite of the $13 \%$ derivation given to states for development and colossal sums of money given to the Niger Delta Agency, which are to provide social amenities to the people (Tor-Anyiin, 2007).

Apart from Middle East, the horn of Africa-areas bordering and including Eritrea, Somalia, Sudan, Ethiopia, another region that captivates world attention in relation to global peace is the Niger Delta caused by youth restiveness. The area knows no peace. Thousands of people are dying every day either through hunger, disease related problems, militant activities, etc. the region housed about 12 million people by 2006 Nigerian Census. More than 6 million of these numbers are youths of productive and majority are unemployed. These are the angry group. It is because of cheating, oppression and outright neglect, keeping them away from their resources, that the people mainly the Ijaws 
agitate for self-determination, and or resource control or restructuring of the federation.

This kind of violence activities exhibit by some of the youth in Nigeria has a great effect on national transformation. It is on this note that Igbo and Ikpa (2013) lamented that the activities of this nature which has become one of the security challenges facing man in the present society. It is commonly reported that poverty, unemployment and lack of access to education among others were responsible for this high level of insecurity in the country.

It is against this backdrop that, this paper is in place to seek for paradigm of tackling forms of violence emanated from youth restiveness in the country.

\section{YOUTH RESTIVENESS}

The National Youth Development Policy (2001) defines youth as people aged 18-35. They constitute about 40 percent of the more than 140 million people of Nigeria. The total population of youth between 10 and 24 in Nigeria was 45.4 million in 2006, which is 34 percent of the total population.

Elegbeleye (2005) defined youth restiveness as a sustained protestation embarked upon to enforce desired outcome from a constituted authority by an organized body of youths. It is marked by violence and disruption of lawful activities.।

Following the poor implementation of the 1963 constitutional provision, the Niger Delta Youths formed a militant group, the Niger Delta Volunteer Service, "to actualize a sovereign state of the Niger Delta in 1966" Aladekomo (2004). This aim differs from that of the National Founders, which was cooperation for a united and virile sovereign state of Nigeria. However, the youths' impatience took the issue of resource control a different dimension, by declaring a sovereign state for absolute control. Part of their independence declaration was, "All former agreements as regards crude oil of the people under taken by the defiance Nigerian Government in the territory have been declared invalid". This statement was tantamount to treason as it was aimed at dismembered of Nigeria, fight against national sustainability.

The declaration of independence for resource control was however arrested at the bud, with military in power. It was under the military from 1994-1995 that the $13 \%$ derivation formula was recommended and approved. However, the $13 \%$ derivation seems to anger the people the more as the money is never used for their benefit. This has rather fueled Youths restiveness in the region, to fight for resource control; as it resulted to formation of more militant youth's associations in the region to fight for resource control; the Movement for the Survival of Ogoni people (MOSOP), The Ijaw Youths Council (IYC) and Movement for the Emancipation of the Niger Delta (MEND) just to mention but a few. These groups represent the characteristics of youth's restiveness in the Niger Delta.

The members of the indignant youths started expressing their anger with the bunking of oil resulting to vandalization of oil installations, taking of expatriate oil workers hostage, attacking oil companies to cart away with valuable; killing of security personnel as well as producing many oil motivated communal and ethnic clashes like the itsekirin/Urhobo and Ijaw. There was also the Atadekoho, Igne-Laba, Obozogbe, Nugu Owobi against Oben community over sharing of benefits from shell petroleum Development Company (SPDC), (Igbiki Owuba, 2002). The movement for the emancipation of the Niger Delta (MEND) detonated a bomb in a military barracks in PortHarcourt and caused other atrocities in the town in pursuance of resource control. Recently, hostage taking for ransom has taken the stage as a strategy to fight for resource control. Whether inter ethnic, intra ethnic or direct assault on the companies, security personnel and hostage taking, one thing is clear, production and operation of the oil companies, the life wire of Nigeria economy is disrupted.

\section{A. Forms of Youth Restiveness}

There are so many violence that can result to youth restiveness some of these violence characters are:

i. Involvement in political thuggery. It is no longer news that some youth are hired as political thugs and touts by desperate politicians to settle scores with their opponents. This is particularly so during electioneering campaigns and on election days. This portends great danger for national unity and development. The reported cases of ballot boxes snatching among other said to have been perpetrated mostly by youths.

ii. As hired assassins by disgruntled politicians, businessmen and women who have an axe to grind with their opponents'. The assassination of the justice minister, Bola Ige in 2002, Harry Marshal in 2003, Dikibbo, early 2004, the assassination attempt on the Governor of Benue State, Mr. George Akume and the former Governor of Kogi State, Prince Abubakar Audu as widely reported in the print and electronic media are a few of such cases.

iii. Disruption in oil prospecting, exploration and mining in the Niger Delta Area through violent attacks and kidnapping of oil workers.

iv. As members of ethnic militias e.g. Bakkassi Boys, Niger Delta Youths OPC, Egbesu, Arewa, Middle Belt Youth, Ijaw Youths to mention just a few.

v. As cult members on campuses. They include the "Black Axe", "Black Scorpion", the Trojan Horse", "the Vikings", The Sea Dogs", "the Buccaneers", and "The Amazons". These names 
conjure up fears and terror. Their members carry firearms, dagger, axes and knives and unleash a reign of terror on innocent students on campus. The activities of cult members have often led to loss of lives and property in Nigerian tertiary institutions.

vi. As religious fanatics during religious motivated violence or crisis.

vii. As members of street gangs such as "Area Boys" in big commercial city of Lagos Right now their activities are fast spreading to other cities in the country.

viii. Armed robbery and other criminal activities such as murder, rape, pick, pocketing, 419, exam malpractices, human trafficking, currency and drug trafficking. A survey conducted by the Federal Ministry of internal Affairs in 1999. Showed that 90 of the total inmates in Nigeria prisons were youth below 30 years (Obieh, 2002).

ix. vandalizatin of $\mathrm{PHCN}$ and NNPC pipelines, installation.

\section{B. Implications of Violent Youth Behavior for National Unity and Sustainability.}

Implications of violent youth behaviours for National unity and development are grave and worth doing something about. These include:

i. Reports in the print and electronic media indicate that the restive youths in the Niger Delta region where crude oil is produced have resorted to kidnapping of oil workers and vandalisation of pipelines. As a result of this crisis, millions of naira in oil revenue has been lost due to disruption in prospecting and production. This has negative impact on the economy as oil accounts for well over $80 \%$ of our revenue. The current spate of kidnapping of oil workers and young children in recent times has led to the withdrawal of foreign workers and loss of huge revenue and investment.

ii. The current activities of ethnic militia, such as Ijaw youths, Niger Delta Youths and OPC to mention just a few have posed great threat to the national development of the country. No meaningful development can take place in place where there is no peace and security for live and property. Besides the much expected foreign investment, wealth creation and employment opportunities will become a mirage, as no foreign investors would hazard investing in a country where the prospects of the investments cannot be guaranteed. Just recently, the United States Government issued a travel warning to its citizens against visiting Nigeria. iii. The proliferation of ethnic solidarity and loyalty to some has tended to undermine Nigeria's quest for a united and indivisible country built on the cardinal principles of unity and faith, peace and progress is greatly jeopardized. Rather, what we have witnessed in recent times is loyalty to ones ethnic group instead of the country. This had been further compounded by the divergent calls from different quarters for confederation and resource control. More often than not, whenever there is an eruption of ethnic or religious crisis, it has always left in its wake destruction of lives and property and the attendant mass movement of people to their states of origin. This development does not augur well for national unity, development and sustainability.

iv. The activities of cult members on campuses have grave implication for national unity, development and sustainability. It is on record that there activities create tension, disrupt academic programmes, cause loss of lives and properties and destroyed during clashes by opposing rival cult members cannot be replaced easily.

v. The implication of child soldiers for national unity and development are obvious. This category of children will be denied the opportunity of being trained to contribute their quota to the development of their country. In addition, they will find it difficult to be integrated in the society as useful member of the citizenry. If they are not rehabilitated, they are most likely to take to violent behaviours/crime. Furthermore, the high rate of politically motivated assassination in the country may not be unconnected with the proliferation illegal firearms in the hands of those who should not have them.

vi. Other implications include the impediment to free movement of people, goods and services through the mounting of roadblocks on the high ways during religious, ethnic and political crisis. This has greatly affected the economy of the country and scares way the much expected investors that the country desperately needs.

vii. Their involvement in unwholesome and criminal behaviours denies them the opportunity of being in school.

\section{CONCLUSION}

This paper examines the causes, forms, implication and youth restiveness for managing violent youth behaviours. It concluded that violent youth poses great threat to the corporate existence of Nigeria and recommended that 
immediate and practicable steps be taken to curb the ugly trends.

\section{RECOMMENDATION}

In other to prevent and stem the high rate of violent behaviors of the youth, the following steps are being recommended:

i. Review of the Educational System so as to make it functional, relevant and responsive to the ever changing needs of the country. Besides, such a view would lay emphasis on the acquisition of manipulative skills for gainful self-employment. This will reduce the high rate of unemployment of our youth.

ii. Government at all tiers should fund education adequately so as to reduce the incessant crisis in the system which often leads to long closure of the universities.

iii. There should be provision of Guidance and counseling to students at all levels of the educational system.

iv. Parents should be more responsive and be alive to their responsibilities by striving to provide the basic needs of their children within their means. They should also monitor the friends their children keep as well as the type of film, video, books and programme they watch on television.

v. Ethical orientation through which family values, respect for life and the inculcation of national consciousness and loyalty to the country should be emphasized.

vi. Governments at all tiers should strengthen and fund all Federal Institutions which represent our national unity adequately so that they could perform their statutory function effectively. These include unity schools, students' exchange patriotism and national consciousness in our youths.

vii. Teachers, parents and significant others in the society should strive to be exemplary in their conduct so that the children could model their behaviours after these desirable behaviours exhibited by them.

\section{REFERENCES}

Appadorai, A. (1975). The substance of politics (11 th edu.), Madras: Oxford University press.

Elegbeleye, O. (2005). Recreational Facilities in Schools: A Panacea for Youth Restiveness. Journal of Human Ecology, 93-98.

Federal Government of Nigeria (2001). National Youth Policy. Available: http://www.thepresidency.gov.za/docs/policy /national youth policy.pdf

Federal Republic of Nigeria (1998), National Policy on Education. Lagos: NERDC.
Igbikiowobu, H. (2002) Irate Youths stom SPD'S Tunu flow station, steals 63.KVA generation, Guardian, p.17.

Madas, C (2007), Youth Restiveness and Violence in Nigeria: Implications for national unity and sustainability. Journal of the National Association of Science, Humanities and Education Research. 5(1), pp 119-125.

Obieh J.O. (2002). Youth deviant behaviors in Nigeria. Cases and solutions. Lagos Badapat Publication.

Tor-Anyiin, S. Niger Delta Youth Restiveness for Resource Control and National Sustainability: Counseling implications. Journal of the National Association of Science, Humanities and Education Research. 5(1) Pp. 126-131.

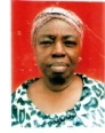

Ogbadu Ruth Alewo was born in Idah, Kogi State Nigeria. HND in Home Economics from College of Agriculture, Yandev-Gboko, Benue State. Postgraduate Diploma in Home Economics Education from University of Nigeria, Nsukka and Masters in Home Economics Education from University of Nigeria Nsukka, Enugu State Nigeria. She held several positions such as Membership of Entertainment Committee, Departmental Examination Officer, Home Economics Student Adviser and Head of Department of Home Economics, Member Global Education Partner, External Moderator College of Education Oju, Monitoring Officer National Examination Council, Member of Nigerian Association of Vocational and Technical Educators, Member of Women in Colleges of Education Ankpa Branch, Membership to Class of Fellows, Strategic Institutes for National Resources and Human Development, and also held two National Exhibitions in Home Economics. Published several journals and participated in National Conferences, attended workshops, Adviser to Women Focus Initiative and Member of Council, Lokoja Zone Nigeria, Nigerian Fellowship of Evangelical Students. She is a Principal Lecturer, Kogi State College of Education, Ankpa, Nigeria.

Ausa Benedict Usman was born in Olowa, Dekina LGA Kogi State Nigeria. Bachelor in Science in Textile and Masters in Science in Textile from Ahmadu Bello University, Zaria, Kaduna State Nigeria. He held several positions in the Department of Home Economics such as Lecturer and Assistant Departmental Examination Officer and Academic Secretary of the Departmental Staff Meetings. He has published one international journal and national conference. He is currently a lecturer with Kogi State Colllege of Education, Ankpa Nigeria.

Atadoga Margaret Ayanigo was born in Okabo, Ofu LGA Kogi State

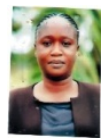
Nigeria. Bachelor in Science in Home Economics and Masters in Science in Clothing and Textile from Kogi State University, Anyigba Nigeria respectively. She is the Seminar Co-ordinator of Home Economics Department Kogi State College of Education Ankpa. She is currently a lecturer in the Department of Home Economics in Kogi State College of Education, Ankpa Nigeria. 